\title{
A new Dicistrovirus from soldier fly Inopus flavus (James) (Diptera: Stratiomyidae), a pest of sugarcane.
}

\author{
Angelique K. Asselin, Kayvan Etabari*, Michael J. Furlong and Karyn N. Johnson \\ School of Biological Sciences, The University of Queensland, Brisbane, Australia \\ *Corresponding author: k.etebari@uq.edu.au
}

\begin{abstract}
:
The native Australian soldier flies, Inopus spp. (Diptera: Stratiomyidae), are agricultural pests of economic importance to the sugarcane industry. While adult soldier flies do not feed on sugarcane, larvae spend one to two-years underground feeding on roots, causing mechanical and systemic damage to crops (Saccharum officinarum L.) that impacts yield. Current measures of pest control commonly target above ground pests and are ineffective against solider fly larvae, highlighting the importance of novel control methods. A screen of the salivary gland transcriptome of Inopus flavus (James) revealed the presence of viral RNA belonging to a potentially novel member of the Dicistroviridae family. Viruses from this family have been found naturally infecting insects from a range of taxonomic groups and they often cause pathogenesis in their hosts. To characterise the genetic and physical properties of the new virus, the positive RNA genome was analysed using a combination of sequencing approaches. The virus genome is organised similarly to members of the Dicistroviridae with two open reading frames (ORF) the first encoding non-structural proteins and the second encoding structural proteins. The genome includes two potential internal ribosomal entry sites (IRES) one within the 5' UTR and the other in the intergenic region (IGR). Based on the amino acid sequences of the non-structural and structural polyproteins encoded by the two ORF soldier fly virus groups within the dicistrovirus family. Virus particles purified from infected larvae and visualised by electron microscopy are icosahedral, non-enveloped, and $30 \mathrm{~nm}$ in diameter. The genetic and physical characteristics of this novel soldier fly virus are consistent with it being a member of the Dicistroviridae.
\end{abstract}

Keywords: Soldier fly, sugarcane, Dicistrovirus, insect virus, RNA virus, soldier fly virus 
Australian soldier flies, Inopus spp. (Diptera: Stratiomyidae), are endemic to eastern Australia and southern Papa New Guinea and Inopus rubriceps has been introduced into the North Island of New Zealand and California, USA [1, 2]. Inopus spp. are pests of economic importance across both their native and introduced ranges where thay attack sugarcane, pasture, horticultural and fodder crops [1]. The subterranean larvae live for 1-2 years and their sucking mode of feeding on roots causes systemic damage to above ground parts of affected plants [3-7]. In sugarcane, feeding presents as inhibited germination and retarded shoot development $[8,9]$ and it can result in significant yield loss. Although the mechanism of systemic damage remains unclear, larval homogenates reduce sugarcane sett germination [10], and feeding on sugarcane roots upregulates venom proteins in larvae, suggesting these proteins could be involved in damage to host tissue $[11,12]$. In contrast, adult soldier flies do not cause plant damage and they are ephemeral, living for 3 to 10 days depending on location, during which time they mate and lay eggs close to the soil surface near host plants [3, 13, Reviewed in 14].

Currently there is no effective control for soldier flies. Management approaches have included targeting of adults with pesticides in the short temporal window after emergence [15] but this is ineffective. Control of larvae is also difficult. Insecticide based approaches have failed due to variable efficacy of compounds and the need to integrate applications with specific growing practices [14, 1618]. The cost, ineffectiveness and negative non-target impacts of pesticides, the lack of effective arthropod natural enemies [19] and poor control provides by previous management practices [Reviewed in 14, 20] have prompted investigations for alternative control measures.

The broad range of hosts, pathology and effects on host behaviour make dicistroviruses appealing as biopesticides for control of agricultural pests. Members of Dicistroviridae infect a variety of arthropod hosts. They principally attack insects and they can have broad host ranges, for example Cricket paralysis virus (CrPV) infects multiple insect orders [21-28]. Arthropod hosts of medical and agricultural importance are infected and viruses attacking agriculturally important hosts include CrPV [26, 27], Aphid lethal paralysis virus (ALPV) [29], Rhopalosiphum padi virus (RhPV) [30, 31], Plautia stali intestine virus (PSIV) [32], Himetobi P virus (HiPV) [33], Homalodisca coagulate virus-1 (HoCV-1) [34] and Solenopsis invicta virus-1 (SINV-1) [35]. Infections vary from asymptomatic and chronic [23, 36-39] to acute and highly pathogenic, resulting in rapid disease progression and host death [26, 29, 40, 41]. Chronic infections, such as those seen with Drosophila C virus (DCV) [39], can be asymptomatic or mildly pathogenic but stress or secondary infections may trigger increased pathogenicity and more rapid disease progression [23, 37, 42-44]. More symptomatic infections commonly present with paralysis [26, 29, 40,41], reduced longevity or fecundity [31, 39], reduced larval and pupal longevity [45] or changes in behaviour [46]. The combination of host range, pathology 
and resulting effects on host interactions with enviroment make dicistroviruses promising for biological control [43].

The Dicistroviridae family is characterised by single stranded, positive sense, non-partite, RNA genomes contained within non-enveloped icosahedral virions approximately $30 \mathrm{~nm}$ in diameter [47]. The 5' end of the viral genome is covalently linked to a viral protein genome-linked (VpG) and ranges between $8-10 \mathrm{~kb}$, encoding two open reading frames (ORF) and poly-adenylated. ORF1 is located at the 5' end and encodes a non-structural polyprotein comprised of an RNA dependent RNA polymerase ( $\mathrm{RdRp}$ ), protease, helicase and $\mathrm{VpG}, \mathrm{ORF} 2$ is separated from ORF1 by an intergenic region (IGR) and encodes a structural capsid polyprotein producing four separate structural proteins VP1, VP2, VP3, and VP4 [47]. Upon translation the polyproteins' are processed into individual components by a virally encoded proteinase [47]. In some members, there is a third overlapping +1 frame ORFx within ORF2 [48-50] that appears to be important for CrPV infection [51]. Dicistroviruses employ a non-canonical method of translation through the use of internal ribosome entry sites (IRES) at both the 5'UTR and IGR for translation of ORF1 and ORF2 respectively. The structure and function of the 5'UTR IRES of dicistroviruses has not been well characterised. Despite an apparent lack of conserved structures across the family, they appear to function as IRESes in vitro and require the recruitment of initiation factors [52-54]. The 5'UTR IRES of CrPV, has been elucidated with the structure and function of a group III IRES. Meanwhile the IGR IRES is group IV, the secondary structure of which allows recruiting of $80 \mathrm{~S}$ ribosomal subunits directly to initiate translation. The IGR IRES of dicistroviruses have been extensively studied and can be categorised as either Type I or II based on conservation of distinct structural elements not necessarily sequence conservation. Triatoviruses and cripaviruses seem to have type I while aparaviruses have type II. The main domains of the IGR IRES include stem loops and bulge regions (L1.1, SLIV, SLV) and pseudoknots (PK I, II, and III). While Type II have an extra stem-loop domain SLIII within PKI and a bigger L1.1 domain the two IRES Types function similarly in initiating translation [55-58]. Here we describe a new soldier fly virus which may prove to be a pathogen of these pests and which could be exploited for their control.

Soldier fly larvae were collected from the stools of infested sugarcane (Saccharum officinarum L.) fields near Hay Point, Mackay, Queensland Australia $\left(21^{\circ} 18^{\prime} 5^{\prime \prime} \mathrm{S}, 149^{\circ} 14^{\prime} 7^{\prime \prime} \mathrm{E}\right)$ as described [12] in February and March 2019, prior to annual emergence of adults. RNA, purified from larvae as described previously and used to generate RNAseq data [12], was also used to synthesise viral cDNA using specific primers (Table 1) with SuperScript ${ }^{\circledR}$ Double-Stranded (Invitrogen by Life technologies) as per manufacturers instructions. Further rounds of cDNA were synthesised using a the SMARTer RACE 5'/3' Kit (Clontech Laboratories, Takara Bio) as per manufacturers instructions. cDNA was 
cloned into the pGEM®-T Easy Vector (Promega) per manufacturers protocol and transformed into competent XL1 Escherichia coli cells by heat shock. Plasmid DNA was purified from positive clones using a ZR Plasmid Miniprep - Classic kit (Zymo Research) following manufacturer's instructions and 600-1000 ng of pure DNA in UltraPure ${ }^{\mathrm{TM}}$ water (Invitrogen)) were sent to the Australian Genome Research Facility for Sanger sequencing using sequencing primers (Table 1). A consensus of the novel soldier fly virus genome was derived using RNAseq data (GSE127658) and Sanger sequencing of cloned cDNA. The 9762 nt RNA genome (excluding poly(A) tail) was compiled using RNAseq data accession number MW357714 (Figure 1A). With an average coverage of 402728 reads per nucleotide, the consensus represents the most prevalent sequence in the RNAseq library, with only 26 single nucleotide variants (SNV), 3 multi nucleotide variants and one deletion with Phred scores above 29 and frequencies above 10\% (Figure 1B and 1C). The consensus was confirmed by Sanger sequencing with 93.35\% homology over $9206 \mathrm{nt}$ excluding the $5^{\star}$ end. Considering the RNA template used for sequencing was derived from a pool of soldier fly larvae the variation between sequences and in the library likely reflects the diversity of the viral population, which is expected as RNA viruses largely exist as quasispecies [59].

Table 1: Nucleotide sequence of primers used in this publication

\begin{tabular}{llll}
\hline Name & Use & Primer Sequence (5'-3') & Tm ( $\left.{ }^{\circ} \mathbf{C}\right)$ \\
\hline 5'RACE GSP 1.1 & cDNA Step 1 PCR & GATTACGCCAAGCTT'GAACCATCCCAATTGGCAAAATCACCCG ${ }^{2}$ & 62 \\
5' cDNA GSP 1.2 & cDNA Step 2 PCR & GATTACGCCAAGCTTTGTGCTTCAGGTATTGGGTCCGATG & 60.8 \\
5'RACE GSP 1.3 & RACE PCR & GATTACGCCAAGCTTGCGCATAGGGAATTACCTGCGACTTC & 68.5 \\
3'RACE GSP2 & RACE PCR & GATTACGCCAAGCTTGCTTCCAAAGCTGGTGGCCCTGT & 64.5 \\
IntFw & RT-PCR Detection & AGCACATTTTAGATATATTGCCCC & 53 \\
IntRv & RT-PCR Detection & TGCGAACTTGAGAACTTGACC & 55.4 \\
M13 Forward & Colony PCR & TGTAAAACGACGGCCAGT & 54 \\
M13 Reverse & Colony PCR & CAGGAAACAGCTATGACC & 50 \\
3'RACE Forward 1 & Sanger Sequencing & TTGGGCAAGAGATAGAACGG & 54.5 \\
3'RACE Reverse 1 & Sanger Sequencing & CAAATGCCGTGGGATTCTTC & 54.4 \\
5'End Forward 1 & Sanger Sequencing & TGCGTATACCATCTATTGCCACA & 56.2 \\
5'End Reverse 1 & Sanger Sequencing & AACACCATCAACAACCATGGGACG & 59.9 \\
\hline
\end{tabular}

${ }^{1}$ Underlined is overlap with the linearized vector pRACE. $\quad{ }^{2}$ Bold is virus sequence

Comparison of the assembled genome to the NCBI-nucleotide database identified sequence similarity with dicistroviruses. The genome organisation of this putative new virus is two ORFs separated by an IGR with both a 5' and 3' UTR and poly(A) tail (Figure 1A). The first ORF predicted 
by CLC Main Workbench with an AUG (Met) start codon and translated using standard genetic code translation encodes a putative non-structural polyprotein containing three motifs an RNA helicase (PF00910.22, E-value: 1.30e-17), Peptidase C3G (PF12381.8, E-Value: 1.10e-4) and RNA dependent RNA polymerase (PF00680.20, E-Value 2.20e-48) (HMMER 3.1b1 (May 2013) in CLC Main Workbench 8.1 using the Pfam-A v32 database) (Figure 1A).

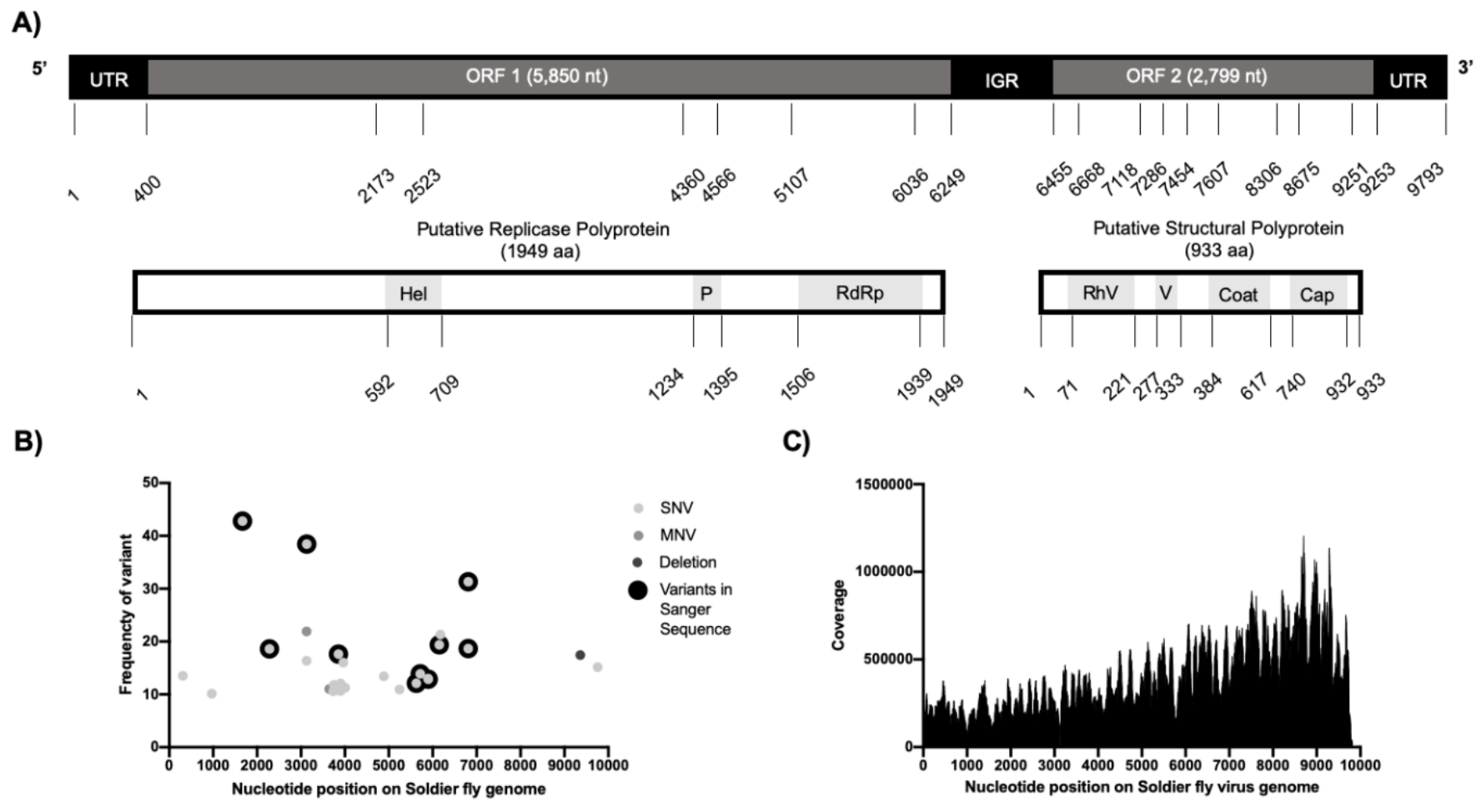

Figure 1: A) Schematic of the organization of the new soldier fly virus genome. The conserved structural domains of the two open reading frames (ORF) predicted by HMMER 3.1b1 (May 2013) in CLC Main Workbench 8.1 search of the PfamA v32 database. Domains for ORF1 include Hel = RNA helicase (PF00910.22, E-value: 1.30e-17), Peptidase = Peptidase C3G (PF12381.8, E-Value: 1.10e-4), RdRp = RNA dependent RNA polymerase (PF00680.20, E-Value 2.20e-48) and for ORF 2 RhV = picornavirus capsid protein (PF00073.20, E-Value: 2.90e-12) V = Cricket paralysis virus VP4 (PF11492.8, E-Value: $1.8 \mathrm{e}-8)$, Coat = Calicivirus coat protein $($ PF00915.20, E-Value: 8.60e-5), Cap = CrPV capsid protein like (PF08762.10, E-Value: 3.3e-17). B) Map of single nucleotide variants (SNV) multi-nucleotide variants (MNV) and deletions present in the RNAseq library with a frequency above $10 \%$ and with quality Phred scores above 29 . There were also high frequency variants found in the Sanger Sequence consensus. Variants appear across the genome with no apparent regions of high variation. C) RNASeq read density plotted along the solider fly virus genome. Y-axis the number of reads mapped to a particular nucleotide of the soldier fly virus genome $\mathrm{X}$-axis. There is higher coverage closer to the 3' end that contains a poly(A) tail.

Translation of ORF2 in dicistroviruses is not intiated by a canonical methionine codon [57, 58], commonly it is GCU (Ala) [Reviewed in 60]. It was not possible to robustly identify conserved motifs of dicistroviruses IRESs in the IGR of the soldier fly virus. Without prediction of IRES structures it was not possible to predict the start codon of reading frame and analysis of ORF2 was conducted from the first in frame methionine. The amino acid sequence encoded by the second ORF 
bioRxiv preprint doi: https://doi.org/10.1101/2020.12.24.411611; this version posted December 24, 2020. The copyright holder for this preprint (which was not certified by peer review) is the author/funder, who has granted bioRxiv a license to display the preprint in perpetuity. It is made available under aCC-BY-NC-ND 4.0 International license.

contains motifs that match structural polyprotein sequence of other dicistroviruses, including picornavirus capdis protein (RhV, PF00073.20, E-Value: 2.90e-12), Cricket paralysis virus VP4 (Dicistro VP4, PF11492.8, E-Value: 1.8e-8), Calicivirus coat protein ( Calic_coat, PF00915.20, EValue: 8.60e-5), CrPV capsid protein like (CrPV, PF08762.10, E-Value: 3.3e-17) (Pfam-A v32 database search on CLC Main Workbench 8) (Figure 1A). The organisation of the RNA genome of soldier fly virus and its sequence homology with other dicistroviruses supports its classification as a member of this family.

A)

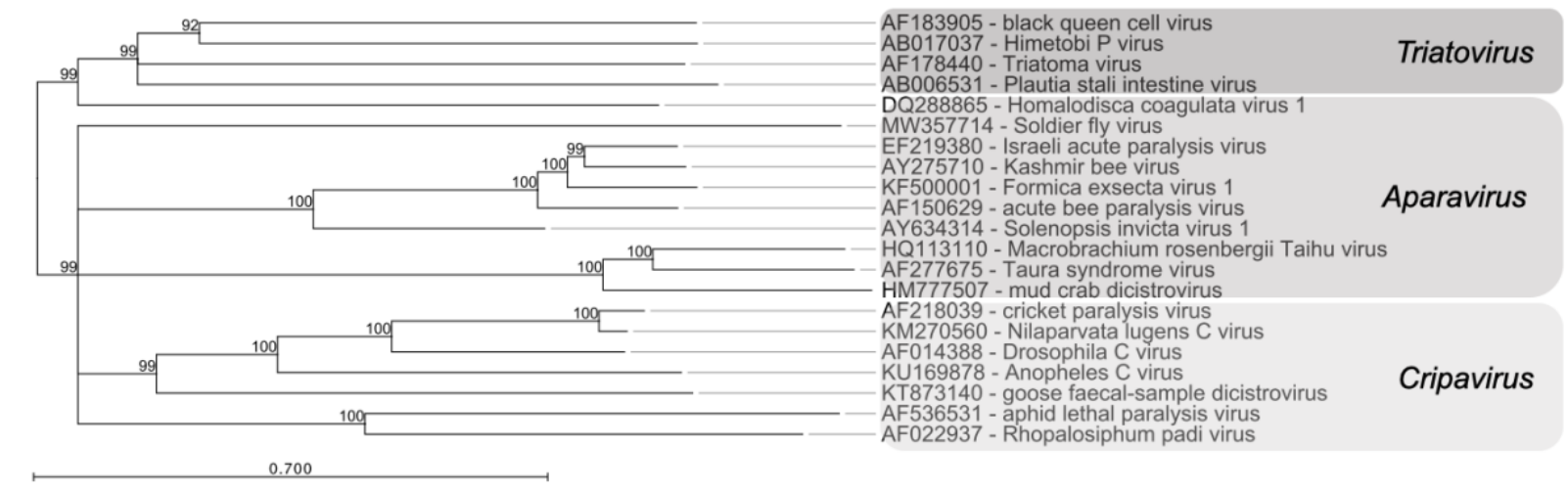

B)

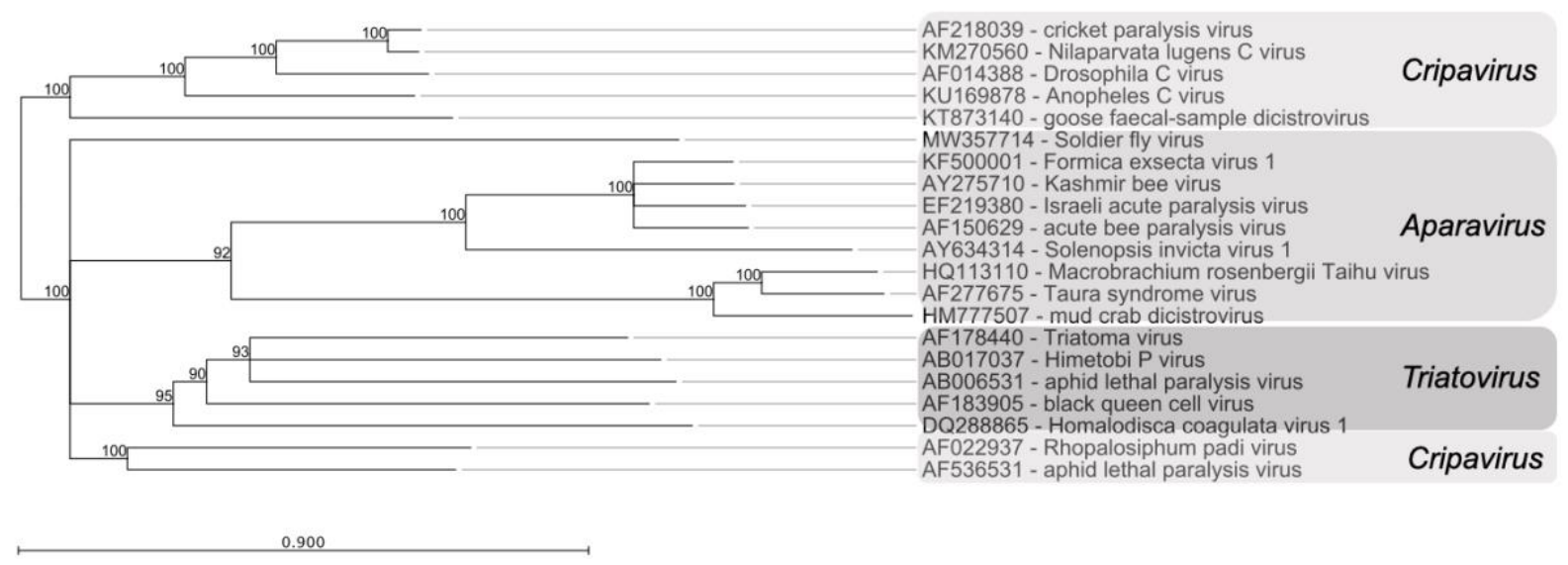

Figure 2: A multiple-sequence alignment of the protein sequence of A) ORF1 and B) ORF2 of the 15 accepted members of the Dicistrovirus family (black) and tentative members from metagenomic data $\left({ }^{*}\right)$ was used to create an un-rooted maximum likelihood phylogeny using a neighbor joining construction method with a WAG protein substitution rate. One thousand bootstraps were performed and only branches with bootstrap values greater than $90 \%$ are shown. Viruses used for the alignment, AB006531 - Plautia stali intestine virus, AB017037 - Himetobi P virus, AF014388 - Drosophila C virus, AF022937 - Rhopalosiphum padi virus, AF150629 - acute bee paralysis virus, AF178440 - Triatoma virus, AF183905 black queen cell virus, AF218039 - cricket paralysis virus, AF277675 - Taura syndrome virus, AF536531 - aphid lethal paralysis virus, AY275710 - Kashmir bee virus, AY634314 - Solenopsis invicta virus, DQ288865 - Homalodisca coagulata virus 1, EF219380 - Israeli acute paralysis virus, HM777507 - mud crab dicistrovirus, HQ113110 - Macrobrachium rosenbergii Taihu virus, KF500001 - Formica exsecta virus 1, KM270560 - Nilaparvata lugens C virus, KT873140 - goose faecal-sample dicistrovirus. 
A multiple-sequence alignment of the protein sequence of ORF1 and ORF2 of the 15 accepted members of the dicistrovirus family and tentative members from metagenomic data was created using the following parameters, Gap open cost $=10$, Gap extension cost $=1.0$, End gap cost $=$ As any other (CLC Main Workbench 8.1). The alignment was used to create an un-rooted maximum likelihood phylogeny using a neighbor joining construction method with a WAG protein substitution rate (CLC Main Workbench 8.1, Figure 2).

Dicistroviruses are grouped into three putative genera, Aparavirus, Cripavirus and Triatovirus depending on the phylogenetic distance of ORF polyprotein sequences and IGR IRES structure. It should be noted however that Aparavirus often separates into two divergent clades, one containing viruses that infect insects and the other viruses that infect crustacea [47]. As mentioned previously the IRES structure of soldier fly virus could not be predicted, but the the phylogenies of ORF1 and ORF2 groups soldier fly virus within the dicistrovirus family (Figure 2).

Pools of 8-10 soldier fly larvae and adults were screened for the presence of virus using RTPCR and all samples were positive (data not show). Positive pools of larvae were homogenised in 500 $\mu \mathrm{L}$ phenylthiourea (PTU) saturated phosphate buffered saline (PBS, pH 7.4) to prevent melanisation. Virus was purified from positive larvae samples by ultracentrifugation on a 10-40\% sucrose-density gradient in phosphate buffer (PB), essentially as described for other dicistroviruses [61, 62]. Briefly, virus was diluted with $\mathrm{PB}$ and centrifuged on a $10 \%$ sucrose cushion $\left(27,000 \mathrm{rpm}, 3 \mathrm{~h}, 12^{\circ} \mathrm{C}\right)$. Supernatant was removed and the pellet was resuspended by vortexing and storage at $4{ }^{\circ} \mathrm{C}$ overnight in $250 \mu \mathrm{L}$ of $\mathrm{PB}$. The resuspended pellet was transferred to a microcentrifuge tube and centrifuged in a sigma 3-16kl benchtop centrifuge for 2-5 minutes at 14,000 rpm to remove any remaining particulate matter. The supernatant was then centrifuged through a $10-40 \%$ sucrose gradient at $12^{\circ} \mathrm{C}$ and 27,000 rpm for 2 hours. Where not specified, centrifuge steps were carried out in in SW41 tubes (Beckmann Coulter, Life Science) using a SW41 swing rotor in an Optima L-80XP Ultracentrifuge (Beckmann Coulter, Life Science). One $\mathrm{mL}$ fractions of the gradient were collected, and viral protein was detected by $12 \%$ SDS-PAGE gel, stained with Coomassie Brilliant Blue G-250. RT-PCR as previously described confirmed the identity of the purified virus as novel soldier fly virus (data not shown). 12\% SDS-PAGE of the purified virus revealed two protein bands approximately 32 and $31 \mathrm{kDa}$ in size and one at $50 \mathrm{kDa}$ (Figure 3A), likely corresponding to the capsid proteins. We we were unable to detect protein bands of lower molecular weight. While dicistroviruses have four capsid proteins (VP1, VP2, VP3 and VP4), sometimes only two dominant bands resolve [63, 64]. Purified virus samples were sent to the Centre for Microscopy and Microanalysis (CMM), The University of Queensland, for transmission electron microscopy imaging. Samples were negatively stained in $2 \%$ uranyl acetate and 
bioRxiv preprint doi: https://doi.org/10.1101/2020.12.24.411611; this version posted December 24, 2020. The copyright holder for this preprint (which was not certified by peer review) is the author/funder, who has granted bioRxiv a license to display the preprint in perpetuity. It is made available under aCC-BY-NC-ND 4.0 International license.

visualized with by electron microscopy. Non-enveloped icosahedral viral particles of an approximate $30 \mathrm{~nm}$-diameter can be seen (Figure 3B), consistent with a member of Dicistroviridae.

A)

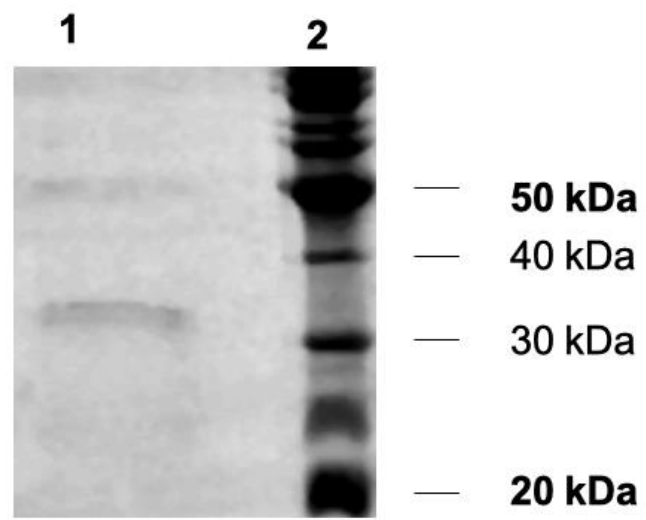

B)

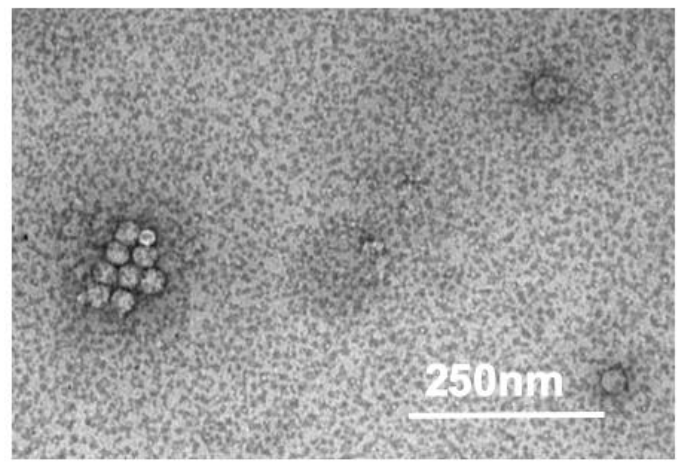

Figure 3: Visualisation of soldier fly virus particles purified from Inopus flavus larvae. A) A Coomassie brilliant blue stained 12\% SDS-PAGE. Lane 1: purified soldier fly virus showing two protein bands approximately $30 \mathrm{kDa}$ and one at $50 \mathrm{kDa}$ likely the viral capsid proteins Lane 2: Benchmark ${ }^{\mathrm{TM}}$ Unstained Protein Ladder. B) Transmission electron microscopy of Solider fly virus particles diluted $1 / 5$ in phosphate buffer ( $\mathrm{pH} 7.2$ ) and negatively stained with $2 \%$ uranyl acetate on a $\mathrm{Cu} 400$ home made glow discharged grid. Virus particles appear either as isolated particles or aggregated. The shape of the viral particles is icosahedral and they are approximately $30 \mathrm{~nm}$-diameter.

\section{Summary}

We identified and purified a novel ss +RNA virus from Australian Inopus spp. larvae that has genetic and physical properties similar to members of the Dicistroviridae family. Dicistrovirus infection pathology, effects on host behaviours including pest behaviours make them appealing as potential biopesticides to control their agriculturally important pest hosts. However, the efficacy of virus soldier fly virus as a viable and efficient biological control agent against solider flies remains to be established and studies investigating on host interactions, pathology and overall effects on pest population dynamics are required.

\section{Author and contributors}

Angelique K. Asselin: Data curation, Formal Analysis, Investigation, Methodology, Validation, Visualization, Writing - original draft

Kayvan Etabari: Conceptualization, Formal Analysis, Investigation, Methodology, Validation Supervision, Writing - review \& editing

Michael J. Furlong: Conceptualization, Funding acquisition, Project administration, Resources, Supervision, Writing - review \& editing

Karyn N. Johnson: Methodology, Resources, Supervision, Writing - review \& editing 


\section{Funding Information}

This project was supported by Sugar Research Australia.

\section{Acknowledgement}

The authors acknowledge the facilities, and the scientific and technical assistance, of the Australian Microscopy \& Microanalysis Research Facility at the Centre for Microscopy and Microanalysis, The University of Queensland.

\section{References}

1. Allsopp P, Robertson L. Biology, Ecology and Control of Soldier Flies Inopus Spp (Diptera, Stratiomyidae) - a Review. Aust J Zool 1988;36:627.

2. Robertson LN. Biogeography of Inopus rubriceps (Macquart) (Diptera: Stratiomyidae). Aust J Entomol 1985;24:321-325.

3. Irwin-Smith V. Studies in Life-Histories of Australian Diptera Brachycera. Proc Linn Soc New South Wales 1920;45:505-530.

4. Hitchcock BE. Studies on the life-cycles of two species of soldier flies (diptera, stratiomyidae) which affect sugarcane in queensland. Bull Entomol Res 1976;65:573-578.

5. Wilcocks CR. Review of the Life-Cycle of the Australian Soldier Fly. Proc New Zeal Weed Pest Control Conf;24. Epub ahead of print 1971. DOI: https://doi.org/10.30843/nzpp.1971.24.10344.

6. Campbell RL, Koehler CS. Annals of the Entomological Society of America. Bull Entomol Soc Am 1971;64:44.

7. Wilcocks CR, Oliver EHA. Life cycle of the Australian soldier fly, Inopus rubriceps (Diptera: Stratiomyidae), in New Zealand. New Zeal J Zool 1976;3:115-125.

8. Samson PR. Effect of Feeding by Larvae of Inopus rubriceps (Diptera: Stratiomyidae) on Development and Growth of Sugarcane. J Econ Entomol 2001;94:1097-1103.

9. Jarvis. Dipterous larva attacking roots of cae. Queensl Agric J 1925;24:100-102.

10. Wilson G. Entomological Investigations. 58th Annu Rep Bull Bur sugar Exp Stn Queensl 1958;79-87.

11. Wilcocks CR. The soldier fly problem. New Zeal J Exp Agric 1974;2:89-93.

12. Etebari K, Lindsay KR, Ward AL, Furlong MJ. Australian sugarcane soldier fly's salivary gland transcriptome in response to starvation and feeding on sugarcane crops. Insect Sci 2020;27:708-720.

13. Irwin-Smith V. Studies in Life-Histories of Australian Diptera Brachycera. Proc Linn Soc New South Wales 1921;46:252-255.

14. Wilcocks CR. Review of control measures for the Australian soldier fly. Proc New Zeal Weed Pest Control Conf 1971;24:155-159.

15. Samson PR. Attempted suppression of Inopus rubriceps (Macquart) (Diptera: Stratiomyidae) by application of insecticides to plant crops of sugarcane. Plant Prot Q 2002;17:148-150.

16. Moller RB. The Solider Fly Pest of Sugar Cane. Cane Grow Q Bull 1965;26-28.

17. Moller RB. Soldier fly experiments. In: Proceedings of the Australian society of sugar cane technologists. Brisbane; 1961. pp. 4-6.

18. Moller RB. Soldier Fly Trials 1964. Cane Grow Q Bull 1965;67-68.

19. Robertson LN. The effects of natural enemies on the population dynamics of sugarcane soldier fly, Inopus rubriceps (Diptera: Stratiomyidae). Agric Ecosyst Environ 1987;19:343-363.

20. Davidson RH, Wrenn N., Robertson L. Renovation techniques for Australian soldier fly infested pastures: a comparison of treatments. In: Proceedings of the New Zealand Weed and Pest Control Conference. pp. 36-39.

21. Johnson KN, Christian PD. A molecular taxonomy for cricket paralysis virus including two new isolates from Australian populations of Drosophila (Diptera: Drosophilidae). Arch Virol 1996;141:1509-1522.

22. Chao Y-C, Young SY, Kim KS. Characterization of a picornavirus isolated from Pseudoplusia includens (Lepidoptera: Noctuidae). J Invertebr Pathol 1986;47:247-257.

23. Anderson DL, Gibbs AJ. Inapparent Virus Infections and their Interactions in Pupae of the Honey Bee (Apis 
mellifera Linnaeus) in Australia. J Gen Virol 1988;69:1617-1625.

24. Plus N, Scotti PD. The biological properties of eight different isolates of cricket paralysis virus. Ann l'Institut Pasteur / Virol 1984;135:257-268.

25. Christian PD, Scotti PD. Picornalike Viruses of Insects. In: Miller LK, Ball LA (editors). The Insect Viruses. Springer, Boston, MA; 1998. pp. 301-336.

26. Reinganum C, O'Loughlin GT, Hogan TW. A nonoccluded virus of the field crickets Teleogryllus oceanicus and T. commodus (Orthoptera: Gryllidae). J Invertebr Pathol 1970;16:214-220.

27. Reinganum C. The Isolation of Cricket Paralysis Virus from the Emperor Gum Moth, Antheraea eucalypti Scott, and its Infectivity towards a Range of Insect Species. Intervirology 1975;5:97-102.

28. Reinganum C, Scotti PD. Serological Relations Between Twelve Small RNA Viruses of Insects. J Gen Virol 1976;31:131-134.

29. Williamson C, Rybicki EP, Kasdorf GGF, Von Wechmar MB. Characterization of a New Picorna-like Virus Isolated from Aphids. J Gen Virol 1988;69:787-795.

30. D'Arcy CJ, Burnett PA, Hewings AD, Goodman RM. Purification and characterization of a virus from the aphid Rhopalosiphum padi. Virology 1981;112:346-349.

31. D'Arcy CJ, Burnett PA, Hewings AD. Detection, biological effects, and transmission of a virus of the aphid Rhopalosiphum padi. Virology 1981;114:268-272.

32. Nakashima N, Sasaki J, Tsuda K, Yasunaga C, Noda H. Properties of a New Picorna-Like Virus of the BrownWinged Green Bug, Plautia stali. J Invertebr Pathol 1998;71:151-158.

33. Toriyama S, Guy PL, Fuji S -i., Takahashi M. Characterization of a new picorna-like virus, himetobi $\mathrm{P}$ virus, in planthoppers. J Gen Virol 1992;73:1021-1023.

34. Hunnicutt LE, Hunter WB, Cave RD, Powell CA, Mozoruk JJ. Genome sequence and molecular characterization of Homalodisca coagulata virus-1, a novel virus discovered in the glassy-winged sharpshooter (Hemiptera: Cicadellidae). Virology 2006;350:67-78.

35. Valles SM, Strong CA, Dang PM, Hunter WB, Pereira RM, et al. A picorna-like virus from the red imported fire ant, Solenopsis invicta: initial discovery, genome sequence, and characterization. Virology 2004;328:151-157.

36. Wigley PJ, Scotti PD. The seasonal incidence of cricket paralysis virus in a population of the New Zealand small field cricket, Pteronemobius nigrovus (Orthoptera: Gryllidae). J Invertebr Pathol 1983;41:378-380.

37. Dall DJ. Inapparent infection of honey bee pupae by Kashmir and sacbrood bee viruses in Australia. Ann Appl Biol 1985;106:461-468.

38. Bailey L, Gibbs AJ. Acute infection of bees with Paralysis Virus. J Insect Pathol 1964;6:395-407.

39. Christian PD. Studies of Drosophila $C$ and A viruses in Australian populations of Drosophila melanogaster. Australian National University; 1987.

40. Maori E, Lavi S, Mozes-Koch R, Gantman Y, Peretz Y, et al. Isolation and characterization of Israeli acute paralysis virus, a dicistrovirus affecting honeybees in Israel: evidence for diversity due to intra- and inter-species recombination. J Gen Virol 2007;88:3428-3438.

41. Bailey L, Gibbs AJ, Woods RD. Two Viruses from Adult Honey Bees (Apis mellifera Linnaeus). Virology 1963;21:390-395.

42. Asgari S, Johnson KN. 9. Dicistroviruses. In: Asgari S, Johnson KN (editors). Insect virology. Norfolk, Engl.: Caister Academic; 2010. pp. 201-229.

43. Bonning BC, Miller WA. Dicistroviruses. Annu Rev Entomol. Epub ahead of print 2010. DOI: 10.1146/annurevento-112408-085457.

44. Xu J, Cherry S. Viruses and antiviral immunity in Drosophila. Dev Comp Immunol 2014;42:67-84.

45. Stevanovic AL, Johnson KN. Infectivity of Drosophila C virus following oral delivery in Drosophila larvae. $J$ Gen Virol 2015;96:1490-1496.

46. Ban L, Ahmed E, Ninkovic V, Delp G, Glinwood R. Infection with an insect virus affects olfactory behaviour and interactions with host plant and natural enemies in an aphid. Entomol Exp Appl 2008;127:108-117.

47. Valles SM, Chen Y, Firth AE, Guérin DMA, Hashimoto Y, et al. ICTV virus taxonomy profile: Dicistroviridae. J Gen Virol 2017;98:355-356.

48. Firth AE, Wang QS, Jan E, Atkins JF. Bioinformatic evidence for a stem-loop structure 5' -adjacent to the IGRIRES and for an overlapping gene in the bee paralysis dicistroviruses. Virol J 2009;6:193.

49. Sabath N, Price N, Graur D. A potentially novel overlapping gene in the genomes of Israeli acute paralysis virus and its relatives. Virol $J$ 2009;6:144.

50. Ren Q, Wang QS, Firth AE, Chan MMY, Gouw JW, et al. Alternative reading frame selection mediated by a tRNA-like domain of an internal ribosome entry site. Proc Natl Acad Sci U S A;109. Epub ahead of print 2012. DOI: 10.1073/pnas.1111303109. 
51. Kerr CH, Wang QS, Moon K-M, Keatings K, Allan DW, et al. IRES-dependent ribosome repositioning directs translation of a +1 overlapping ORF that enhances viral infection. Nucleic Acids Res 2018;46:11952-11967.

52. Royall E, Woolaway KE, Schacherl J, Kubick S, Belsham GJ, et al. The Rhopalosiphum padi virus 5' internal ribosome entry site is functional in Spodoptera frugiperda 21 cells and in their cell-free lysates: implications for the baculovirus expression system. J Gen Virol 2004;85:1565-1569.

53. Woolaway KE, Lazaridis K, Belsham GJ, Carter MJ, Roberts LO. The 5' Untranslated Region of Rhopalosiphum padi Virus Contains an Internal Ribosome Entry Site Which Functions Efficiently in Mammalian, Plant, and Insect Translation Systems. J Virol 2001;75:10244-10249.

54. Terenin IM, Dmitriev SE, Andreev DE, Royall E, Belsham GJ, et al. A Cross-Kingdom Internal Ribosome Entry Site Reveals a Simplified Mode of Internal Ribosome Entry. Mol Cell Biol 2005;25:7879-7888.

55. Pfingsten JS, Costantino DA, Kieft JS. Conservation and Diversity Among the Three-dimensional Folds of the Dicistroviridae Intergenic Region IRESes. J Mol Biol 2007;370:856-869.

56. Nakashima N, Uchiumi T. Functional analysis of structural motifs in dicistroviruses. Virus Res 2009;139:137147.

57. Cevallos RC, Sarnow P. Factor-Independent Assembly of Elongation-Competent Ribosomes by an Internal Ribosome Entry Site Located in an RNA Virus That Infects Penaeid Shrimp. J Virol 2005;79:677-683.

58. Hatakeyama Y, Shibuya N, Nishiyama T, Nakashima N. Structural variant of the intergenic internal ribosome entry site elements in dicistroviruses and computational search for their counterparts. RNA 2004;10:779-786.

59. Lauring AS, Andino R. Quasispecies Theory and the Behavior of RNA Viruses. PLoS Pathog 2010;6:e1001005.

60. Jan E. Divergent IRES elements in invertebrates. Virus Res. Epub ahead of print 2006. DOI: 10.1016/j.virusres.2005.10.011.

61. Johnson KN, Zeddam J-L, Ball LA. Characterization and Construction of Functional cDNA Clones of Pariacoto Virus, the First Alphanodavirus Isolated outside Australasia. J Virol 2000;74:5123-5132.

62. Scotti PD. Cricket Paralysis Virus Replicates in Cultured Drosophila Cells. Intervirology 1976;6:333-342.

63. Jousset FX, Bergoin M, Revet B. Characterization of the Drosophila C virus. J Gen Virol 1977;34:269-283.

64. Nakashima N, Sasaki J, Tsuda K, Yasunaga C, Noda H. Properties of a New Picorna-Like Virus of the BrownWinged Green Bug,Plautia stali. J Invertebr Pathol 1998;71:151-158. 